2012, Vol. 1, Issue 1-2

International Court of Justice

\title{
MARITIME DELIMITATION IN THE BLACK SEA: \\ THE ROMANIA V. UKRAINE CASE
}

\author{
Marcin Kałduński*
}

\section{Introductory Observations}

The dispute discussed herein was between Romania and Ukraine and concerned the establishment of a single maritime boundary delimiting the continental shelf and exclusive economic zone in the Black Sea ${ }^{1}$. The International Court of Justice (hereinafter "ICJ") has, on many previous occasions, discussed questions concerning maritime delimitation and has a wealthy case-law on the subject. It has delimited (in cases where it considered that it enjoyed jurisdiction to hear the dispute) certain maritime areas in the North $\mathrm{Sea}^{2}$, the Aegan $\mathrm{Sea}^{3}$, the Mediterranean

* Nicolas Copernicus University in Torun.

1 Maritime Delimitation in the Black Sea (Romania v. Ukraine), Judgement of 3.2.2009, I.C.J. Reports 2009. („Judgment”).

2 Fisheries (United Kingdom v. Norway), Judgment of 18.12. 1951, I.C.J. Reports 1951; North Sea Continental Shelf (Federal Republic of Germany/Netherlands, Federal Republic of Germany/Denmark), Judgment of 20.2.1969, I.C.J. Reports 1969.

3 Aegean Sea Continental Shelf (Greece v. Turkey), Judgment of 19.12. 1978, I.C.J. Reports 1978. 
Sea between Tunisia and Libya ${ }^{4}$ and between Malta and Libya ${ }^{5}$, the Gulf of Maine ${ }^{6}$, the Gulf of Fonseca ${ }^{7}$, areas between Greenland and the island of Jan Mayen ${ }^{8}$, maritime zones between Guinea-Bissau and Senegal ${ }^{9}$ and between Qatar and Bahrain ${ }^{10}$, Lake Chad ${ }^{11}$, the Straits of Singapore ${ }^{12}$ and the Black Sea in the case between Romania and Ukraine. Additionally, two more cases are pending before the Court concerning the delimitation of certain maritime zones in the Caribbean $\mathrm{Sea}^{13}$ and the Pacific Ocean ${ }^{14}$. Arbitral tribunals have also been engaged in developing the methodology of maritime delimitation and a few arbitral disputes concerning the delimitation of maritime zones have, as will be shown below, already been endorsed by the $\mathrm{ICJ}^{15}$. Last but not least, the International Tribunal for

4 Continental Shelf (Tunisia/Libyan Arab Jamahiriya), Judgment of 24.2.1982, I.C.J. Reports 1982.

5 Continental Shelf (Libyan Arab Jamahiriya/Malta), Judgment of 3 .6. 1985, I.C.J. Reports 1985.

6 Delimitation of the Maritime Boundary in the Gulf of Maine Area (Canada/United States of America), Judgement of 12.10.1984, I.C.J. Reports 1984.

7 Land, Island and Maritime Frontier Dispute (El Salvador/Honduras: Nicaragua intervening), Judgment of 11.9.1992, I.C.J. Reports 1992.

8 Maritime Delimitation in the Area between Greenland and Jan Mayen (Denmark v. Norway), Judgment of 14 .6. 1993, I.C.J. Reports 1993.

9 Maritime Delimitation between Guinea-Bissau and Senegal (Guinea-Bissau v. Senegal), Order of 8.11. 1995, I.C.J. Reports 1995.

10 Maritime Delimitation and Territorial Questions between Qatar and Bahrain (Qatar v. Bahrain), Judgment of 16 .3. 2001, I.C.J. Reports 2001.

11 Land and Maritime Boundary between Cameroon and Nigeria (Cameroon v. Nigeria: Equatorial Guinea intervening), Judgment of 10.10.2002, I.C.J. Reports 2002.

12 Sovereignty over Pedra Branca/Pulau Batu Puteh, Middle Rocks and South Ledge (Malaysia/Singapore), Judgment of 23 .5. 2008, I.C.J. Reports 2008.

13 Territorial and Maritime Dispute between Nicaragua and Honduras in the Caribbean Sea (Nicaragua v. Honduras), Judgement of 8.10.2007, I.C.J. Reports 2007 (preliminary objections, the case is pending and public hearing were concluded on 4.5.2012).

14 Maritime Dispute (Peru v. Chile), the application filed on 16.1.2008. The Court scheduled public hearings from 3 to 14.12.2012.

15 For example: Anglo-French Continental Shelf Case, Decision 30.6.1977, RIAA, Vol. XVIII; Barbados v. The Republic of Trinidad and Tobago, Award of 11.4.2006, RIAA, Vol. XXVII; Delimitation of the Maritime Boundary between Guinea and Guinea-Bissau, Decision of 14.2.1985, RIAA, Vol. XIX, Decision of 31.7.1989, RIAA, Vol. XX; Award of the Arbitral Tribunal in the Second Stage of the Proceedings between Eritrea and Yemen (Maritime Delimitation), Award of 17.12.1999, RIAA, Vol. XXII. 
the Law of the Sea has handed down judgment in a maritime delimitation dispute in which it endorsed the methodology established by the ICJ and made particular reference to the Black Sea case ${ }^{16}$. Moreover, the ICJ was the first adjudicative body to delimit the continental shelf beyond 200 nautical miles.

The Court has made an important contribution to the development of the law of the sea ${ }^{17}$. Its case-law has a strong influence on State practice concerning maritime delimitation. It also had an impact on the drafting of the United Nations Convention on the Law of the Sea (hereinafter "UNCLOS") at the Third United Nations Conference on the Law of the Sea (1973-1982). It should be borne in mind that the ICJ developed the notion of equitable principles in the law of the sea since it was obliged to refer to customary international law and treaty law, namely the 1958 Geneva Conventions and UNCLOS, which have formed the applicable law with respect to maritime delimitation. Since 1969, the Court has established a methodology on maritime delimitation, although it did not refer to a particular "methodology" until 2009 when it delivered its judgment in the present case ${ }^{18}$. This step confirmed or concluded what can be referred to as the overall process of establishing the delimitation methodology of maritime zones, which now consists of three different and independent stages.

The process of establishing the above methodology can be divided into three phases ${ }^{19}$. The first relates to judgments handed down between 1969 and 1982, in which the Court principally relied on customary international law and the Geneva Conventions to develop the basic elements of maritime delimitation ${ }^{20}$. The judgment in the North Sea

16 Dispute concerning Delimitation of the Maritime Boundary between Bangladesh and Myanmar in the Bay of Bengal (Bangladesh/Myanmar), International Tribunal for the Law of the Sea, judgment of 14.3.2012, case No. 16.

17 See: R. Kolb, Case Law on Equitable Maritime Delimitation: Digest and Commentaries, Martinus Nijhoff, The Hague, 2003.

18 Judgment, chapter 7; at para. 174. However, the Arbitral Tribunal was the first adjudicating body to refer to "the methodology of delimitation". See: Barbados v. The Republic of Trinidad and Tobago, supra note 15, at paras. 68, 307, 338.

19 See: D. R. Rothwell, T. Stephens, The International Law of the Sea, Hart Publishing, Oxford, Portland, 2010, at p. 393.

20 Convention on the Territorial Sea and the Contiguous Zone, 29.4.1958, 516 UNTS 205; Convention on the Continental Shelf, 29.4.1958, 499 UNTS 311. 
Continental Shelf cases formed the basis of the fundamental rules which were subsequently developed by further judicial and arbitral decisions. The second phase concerns the period between 1982 and 1994, up to the date of the entry into force of UNCLOS, whereas the last phase continued until 2009 when the Court specifically referred to a delimitation methodology in the Romania v. Ukraine dispute. Thus, a period of more than 40 years was needed to conclude the process of establishing the methodology of maritime delimitation. However, it must be borne in mind that maritime delimitation is a complex and difficult legal issue ${ }^{21}$. It deals with the essential interests of riparian States, which cannot be taken lightly, and it is accordingly unsurprising that the ICJ refined the methodology of maritime delimitation gradually, relying on State practice and leaving States a certain measure of discretion as to how formulate the rules on maritime delimitation in the jurisprudence of the Court.

The purpose of maritime delimitation is to establish a single maritime boundary between adjacent or opposite States. Such a boundary should not be confused with the boundary separating the territories of States. The Court explained that a maritime boundary "defines the limits of maritime zones where under international law coastal States have certain sovereign rights for defined purposes," whereas a territorial boundary "defines the territorial limits of State sovereignty"22. Accordingly, a single maritime boundary separates the exercise of sovereign rights which each coastal State possesses under international law for defined purposes. A territorial boundary, conversely, concerns the limits of the territorial sovereignty of neighboring States. By virtue of its sovereignty, each State has exclusive competence over its territory to the exclusion of any other State ${ }^{23}$. Territorial disputes rest on an assumption of concurring sovereignties, which means that an international court or tribunal "has

21 See: T. Wasilewski, Delimitacja szelfu kontynentalnego. Studium prawnomiędzynarodowe. [The Delimitation of the Continental Shelf], Wydawnictwo Uniwersytetu Mikołaja Kopernika, Toruń, 1994; D. R. Rothwell, T. Stephens, supra note 19, at pp. 383-412; G. J. Tanja, The Legal Determination of International Maritime Boundaries: The Progressive Development of Continental Shelf, EFZ and EEZ Law, Kluwer Law and Taxation Publisher, Deveter Boston 1990.

22 Judgment, at para. 217.

23 Island of Palmas Case (Netherlands v. USA), Award of 4 .4. 1928, RIAA, Vol. 2, at p. 838. 
to determine which of the Parties has produced the more convincing proof of title"24. Maritime delimitation disputes do not concern the determination of a better title to a disputed territory but, rather, draw a line of separation between maritime zones of adjacent or opposite States under the applicable law which have the overlapping claims to these zones. As opposed to territorial claims, a disputed maritime zone may be divided between the States concerned.

The dispute between Romania and Ukraine concerned the delimitation of their respective continental shelves and exclusive economic zones. The main issue leading to the dispute was Serpents' Island (also called Snake Island or Ostrov Zmeinyy), a Ukrainian natural feature, located approximately 20 nautical miles to the east of the Danube delta. The maritime area near Serpents' Island has become important in the policy of both States since explorations and research conducted in the area showed that substantial amounts of natural gas may be found around the Island. The Ukrainian territorial sovereignty over Serpents' Island had been contested by Romania until 1997, when it formally confirmed that the Island belonged to Ukraine. Serpents' Island is above water at high tide and has an area of approximately $0.17 \mathrm{sq} \mathrm{km}$. The Island is not inhabited, although Ukraine asserted before the ICJ that it is an inhabited area. It lacks fresh water, but it has had a lighthouse since the beginning of the XIXth century and Ukraine built structures (e.g., a bank) and a pier on it, probably to reinforce its claims to adjacent marine areas.

The core issue in the dispute was whether such a small islet could impact on the delimitation of the continental shelf and the exclusive economic zone. Ukraine was of the view that Serpents' Island could have its own continental shelf and exclusive economic zone according to Article 121 (2) of UNCLOS, whereas Romania denied such a claim and argued that, by virtue of Article 121 (3) of UNCLOS, Serpents' Island is a rock and could have no maritime zones except the territorial sea. The Court underlined that "the task of delimitation consists in resolving the overlapping claims by drawing a line of separation of the maritime

24 Minquiers and Ecrehos (France/United Kingdom), I.C.J. Reports 1953, at p. 52. See also: J.-G. Mahinga, La délimitation de la frontière maritime entre la Roumanie et l'Ukraine dans la mer Noire, 'Journal de Droit International' 2010, Vol. 137, No. 4, at pp. 1158-1160 . 
areas concerned"25, but it did, however, refuse to consider Article 121 with respect to the island. As the case law shows, this is not the first dispute in which the Court declined to pronounce on the subject, although substantial literature has been devoted to the problems of islands and rocks in the law of the sea ${ }^{26}$ and the ICJ could thus have clarified or

25 Judgment, at para. 77.

26 A. B. Alexopolous, The Legal Regime of Uninhabited Islets and Rocks in International Law: the Case of the Greek Seas, 'Revue Hellénique de Droit International' 2003, Vol. 56, pp. 131-151; D. Anderson, Islands and Rocks in the Modern Law of the Sea, [in:] M. H. Nordquist et al. (ed.), 'The Law of the Sea Convention : US Accession and Globalization', Martinus Nijhoff, Leiden 2012, at pp. 307-321; J. Charney, Rocks that Cannot Sustain Human Habitation, 'American Journal of International Law' 1999, Vol. 93, at pp. 863-878; S. Karagiannis, Les rochers qui ne se prêtent pas à l'habitation humaine ou à une vie économique propre et le droit de la mer, 'Revue Belge de Droit International' 1996, Vol. 29, at pp. 559-624; R. Kolb, L'interprétation de l'article 121 paragraphe 3, de la Convention de Montego Bay sur le droit de la mer: les rochers qui ne se prêtent pas à l'habitation humaine ou à une vie économique propre, 'Annuire Français de Droit International' 1994, Vol. 40, at pp. 876-909; B. Kwiatkowska, A. H. A. Soons, Entitlement to Maritime Areas of Rocks which Cannot Sustain Human Habitation or Economic Life of their Own, 'Netherlands Yearbook of International Law' 1990, Vol. 21, at pp. 129-181; R. Lavalle, Not Quite a Sure Thing: The Maritime Areas of Rocks and Low-Tide Elevations Under the UN Law of the Sea Convention, 'The International Journal of Marine and Coastal Law' 2004, Vol. 19, No. 1, at pp. 43-69; A. M. Lopez, El Regimen de la Islas en el Actual Derecho del Mar, 'Revista Española de Derecho Internacional' 1986, Vol. 38, at pp. 151-170; A. G. Oude Elferink, Clarifying Article 121 (3) of the Law of the Sea Convention: The Limits Set by the Nature of International Legal Processes, 'Boundary \& Security Bulletin' 1998, Vol. 6, No. 2, at pp. 58-58; B. Oxman, On Rocks and Maritime Delimitation, [in:] M. Arsanjani et al (ed.), 'Looking to the Future : Essays on International Law in Honor of W. Michael Reisman', Martinus Nijhoff, Leiden 2010, Vol. I, at pp. 893-906; V. Prescott, C. H. Schofield, The Maritime Political Boundaries of the World, Martinus Nijhoff, Leiden 2005, at pp. 57-91; C. H. Schofield, Islands or Rocks - is that the Real Question?: the Treatment of Islands in the Delimitation of Maritime Boundaries, [in:] M. H. Nordquist et al. (ed.), 'The Law of the Sea Convention : US Accession and Globalization', Martinus Nijhoff, Leiden 2012, at pp. 322-340; C. H. Schofield, The Trouble with Islands: The Definition and Role of Islands and Rocks in Maritime Boundary Delimitation, [in:] S.-Y. Hong, J. M. Van Dyke (eds), 'Maritime Boundary Disputes, Settlement Procedures, and the Law of the Sea', Martinus Nijhoff, Leiden 2009, at pp. 19-37; K. Serita, Some Legal Aspects of Territorial Disputes over Islands, [in:] S.-Y. Hong, J. M. Van Dyke (eds), 'Maritime Boundary Disputes, Settlement Procedures, and the Law of the Sea', Martinus Nijhoff, Leiden 2009, at pp. 137-144; C. Symmons, The Rockall Dispute Deepens, 'International and Comparative Law Quarterly' 1986, Vol. 35, at pp. 344-373; J. M. Van Dyke, R. A. Brooks, Uninhabited Islands: Their 
enriched the understanding of the notions of island and rock within the meaning of Article 121 of UNCLOS. The Court, however, refused to do so but simultaneously ruled that tiny Serpents' Island should have no impact whatsoever on the maritime boundary, referring to the geographic circumstances of the area concerned and thereby confirming its previous reluctance to apply Article 121 in delimitation disputes.

The Court distinguished two preliminary issues which had to be dealt with in the correct order before the ICJ could entertain the questions concerning the methodology of the maritime delimitation. Firstly, it had to decide on the determination of the starting-point of the delimitation as a function of the land boundary and territorial sea boundary, as already determined by the States. Secondly, the ICJ considered whether there existed an agreed maritime boundary around Serpents' Island and what was the nature of such boundary. In particular, the Court was obliged to give an answer to the question whether the boundary separated the territorial sea of Ukraine from the continental shelf and the exclusive economic zone of Romania, as claimed by the latter and denied by the former ${ }^{27}$. This point is discussed in Section 4.

In terms of its structure, this article begins with a review of the proceedings of the dispute (Section 2). Section 3 describes the applicable law. Sections 4, 5, 6 and 7 present a detailed discussion of the Court's handling of various issues concerning maritime delimitation, in the following order: (4) existing maritime delimitation; (5) relevant coast; (6) relevant maritime area; (7) delimitation methodology. Section 8 concludes with a set of observations contained in summary format. Section 7 is of special relevance since it describes in detail the three stages of maritime delimitation with respect to the continental shelf and the exclusive economic zone of both States.

\section{Proceedings before the International Court of Justice}

The questions concerning the delimitation of the north-western part of the Black Sea had been disputed since the end of the Second World War.

Impact on the Ownership of the Ownership of the Ocean's Resources, 'Ocean Development \& International Law' 1983, Vol. 12, at pp. 265-300.

27 Judgment, at para. 43. 
Romania concluded a series of treaties with the USSR and, subsequently, Ukraine which is one of the successor States as regards the USSR treaties in respect of the Black Sea ${ }^{28}$. On 2.6.1997 Romania and Ukraine signed the Treaty on Good Neighbourliness and Co-operation. They also concluded on the same date the Additional Agreement constituted by an exchange of letters which referred to Article 2 of the Treaty ${ }^{29}$. According to the Agreement, both States were obliged to negotiate an agreement on the delimitation of the continental shelf and the exclusive economic zones in the Black Sea. Paragraph 1 of the Agreement may be regarded as pactum de contrahendo, since the States obliged themselves to conclude a treaty on the régime of their border within a reasonable period of time, but not later than 2 years from the date of entery into force of the Treaty. Pactum de contrahendo is a preliminary agreement to conclude a final agreement. When expressed with sufficient precision, it creates valid obligations ${ }^{30}$. In the present case, all the criteria were fulfilled to enable the clause contained in Article 1 to be treated as pactum de contrahendo.

However, despite an extensive debate and 34 rounds of negotiations, no such agreement was reached. Therefore, on 16.9.2004, Romania instituted proceedings before the Court and invoked as the basis of the Court's jurisdiction the compromissory clause embodied in para. 4(h) of the Agreement. As the Court rightly observed, its judgment acts

28 Ibid., at para. 175.

29 Ibid., at paras. 1, 18.

30 A. McNair, The Law of Treaties, Clarendon Press, Oxford 1961, at p. 27. It is necessary to distinguish between pactum de contrahendo and pactum de negotiando. See: U. Beyerlin, Pactum de contrahendo und pactum de negotiando im Völkerrecht?, 'Zeitschrift für ausländisches öffentliches Recht und Völkerrecht' 1976, Vol. 36, at pp. 407-443; J. Gilas, Pactum de contrahendo w prawie międzynarodowym publicznym [Pactum de Contrahendo in Public International Law], 'Zeszyty Naukowe Uniwersytetu Mikołaja Kopernika w Toruniu, Nauki Humanistyczno-Społeczne', Vol. 23, prawo VII, at p. 135; G. Schwarzenberger, International Law, Vol. I: International Law as Applied by International Courts and Triubnals, Stevens Press, London 1957, at p. 220. The questions concerning pactum de contrahendo were discussed [in:] Tacna-Arica question (Chile, Peru), Opinion and Award of 4.3.1925, RIAA, Vol. II, at p. 929; Affaire des biens britanniques au Maroc espagnol (Espagne contre Royaume-Uni), Raport of 1.5.1925, RIAA, Vol. II, at p. 725; Railway Traffic between Lithuania and Poland, Advisory Opinion of 15.10.1931, P.C.I.J. Series A/B, No. 42, at p. 116; International Status of South West Africa, Advisory Opinion of 11.7.1950, I.C.J. Reports 1950, at pp. 139-140. 
as a substitute for the non-existent agreement between the States in question $^{31}$. In the meantime, on 17.7.2003, the States agreed to conclude a Treaty on the Romanian-Ukrainian State Border Régime, Collaboration and Mutual Assistance on Border Matters which delimited the territorial sea between them.

The submissions of Romania and Ukraine have been fully presented in their respective written memorials and in the judgment ${ }^{32}$.

After extensive deliberation, the Court decided that the line of the single maritime boundary delimiting the continental shelf and the exclusive economic zones respected the 12-nautical mile arc of the territorial sea of Ukraine around Serpents' Island and further runs according to the points established by the Court which, generally, were in favour of Romania's submissions.

\section{Applicable Law}

First of all, the Court dealt with the law applicable to the dispute. The ICJ is obliged to decide disputes in accordance with international law, as stipulated in Article 38(1) of its Statute. Nonetheless, the Court emphasised the special role of treaties in force between Romania and Ukraine. Both States are parties to UNCLOS and there was no contention between the States as to the application of that Convention to the present delimitation dispute. Especially, the Court emphasised Articles 74 and 83 which, respectively, are relevant for the delimitation of the exclusive economic zone and the continental shelf ${ }^{33}$. However, the States disagreed as to the principles concerning delimitation listed in sub-paragraphs (a) to (e) of paragraph 4 of the 1997 Additional Agreement ${ }^{34}$. The Court decided that, having in mind the chapeau of the paragraph, those principles were to be taken into account by the States only in their negotiations and

31 Ibid., at para. 29.

32 See: ibid., at paras. 11-13.

33 Ibid., at para. 31.

34 See: Counter-Memorial of Ukraine, at paras. 6.10-6.21; Rejoinder of Ukraine, at paras. 2.22-.2.30; Reply of Romania, at paras. 2.1-2.3; For the text of the said paragraph see: Judgment, at paras. 33, 41. 
therefore they did not constitute the law to be applied by the ICJ ${ }^{35}$. This did not mean that those principles could not be applied by the Court at all. They still could be applied to the extent that they formed part of the relevant rules of international law which are determined in Articles 74 (1) and 83 (1) of UNCLOS ${ }^{36}$. Moreover, the Court pointed to the fact that UNCLOS entered into force as between those States in 1999. Hence, it came to the conclusion that the intention of the parties to the 1997 Agreement had been to apply those principles to the stage of negotiations only, whereas the relevant provisions of UNCLOS were applicable before the Court. At the same time, the Court remained silent on the issue as to whether Romania and Ukraine specifically agreed in 1997 a special set of principles which govern the delimitation of their zones in the Black Sea. Perhaps it did so because Romania, which favoured the application of the 1997 Agreement, simply did not raise any such argument. Nonetheless, it needs to be underlined that the principles set forth in the 1997 Agreements are covered by UNCLOS.

Finally, the Court rejected the Romanian argument that its declaration made upon signing and ratifying UNCLOS had been accepted by Ukraine ${ }^{37}$. According to the relevant part of the declaration, uninhabited islands without economic life can in no way affect the delimitation of maritime spaces belonging to the mainland coasts of coastal States. The ICJ observed that, under Article 310 of UNCLOS, States are not precluded from making such declarations. However, such declarations or statements may not purport to exclude or modify the legal effect of the provisions of UNCLOS in their application to the State making the declaration. The Court decided to apply the relevant provisions of UNCLOS as interpreted in its jurisprudence, in accordance with Article 31 of the VCLT which codifies customary rules on treaty interpretation ${ }^{38}$. It arrived at the terse

35 Judgment, at para. 41. The chapeau provides that " $t]$ he Government of Ukraine and the Government of Romania shall negotiate an Agreement on the delimitation of the continental shelf and the exclusive economic zones in the Black Sea, on the basis of the following principles and procedures." (emphasis added by the ICJ).

36 Ibid., at para. 41.

37 Ibid., at paras. 35, 42. See: Memorial of Romania, at paras. 8.20-8.30.

38 In various cases, the Court directly referred to the Vienna rules of treaty interpretation which "may in many respects be considered as a codification of existing customary international law on the point". See: Arbitral Award of 31.7.1989 (Guinea- 
conclusion that Romania's declaration had no bearing on the Court's interpretation. Perhaps the Court decided thus since Romania's declaration intended to modify the legal effect of Article 121 of UNCLOS and did not, for example, aimed to harmonize Romanian laws and regulations with the provisions of UNCLOS, as provided for in Article 310 of UNCLOS.

\section{Existing Maritime Delimitation between States}

There were two preliminary issues to be dealt with by the Court before it could begin delimitating the maritime zones of the disputing States. The first question concerned the starting-point from which such delimitation should begin. The second issue was raised by Romania, which contended that the States had already established a line dividing the territorial sea of Ukraine and the continental shelf and exclusive economic zone of Romania.

\subsection{The starting-point of the delimitation}

As stated in the introductory observations to this article, both States applied the equidistance method in their maritime claims, but differed as to the starting-point of the delimitation ${ }^{39}$. The crucial element in establishing the starting-point was the role to be given to Serpents' Island in the process of delimitation. Romania argued that delimitation should begin at a point on the outer limit of the island's territorial sea, to the east of the island ${ }^{40}$. Ukraine argued to the contrary. It claimed that the delimitation process should start at the endpoint agreed in the 2003 Border Treaty Régime, to the west of the island. The Court adjudged in

Bissau v. Senegal), Judgement of 12.11.1991, I.C.J. Reports 1991, at para. 48. See also: Territorial Dispute (Libyan Arab Jamahiriya/Chad), Judgement of 3.2.1994, I.C.J. Reports 1994, at para. 41; Oil Platforms (Islamic Republic of Iran v. United States of America), Judgment of 12.12.1996, I.C.J. Reports 1996, at para. 23; Pulp Mills on the River Uruguay (Argentina v. Uruguay), Judgement of 20.4.2010, I.C.J. Reports 2010, at paras. 64-65.

39 For better understanding of the issue, see: Figure 5-1, 5-2 (Map 134 Annexed to the 1949 General Procès-Verbal) and 5-11 in the Counter-Memorial of Ukraine, at pp. 76-77, 98-99.

\footnotetext{
40 Judgment, at paras. 44-49.
} 
favour of Ukraine whilst, however, agreeing largely with the Romanian argument of the mainland-only delimitation approach.

Romania invoked a number of agreements concluded with the Soviet Union and Ukraine. It referred to the 1949, 1963 and 1974 General Procès-Verbals and to the 1949 and 1961 Border Treaties between Romania and USSR. According to Romania, map 134 attached to the 1949 General Procès-Verbal confirmed its view that the starting-point of delimitation should be the point to the east of Serpents' Island ${ }^{41}$.

Ukraine disagreed and highlighted the 2003 State Border Régime Treaty which set the final point of the State border to the east of the island. Therefore, maritime spaces beyond this point had not been delimited. Ukraine argued that none of the agreements invoked by Romania had identified the status of the waters to the south of the territorial sea of the island, nor had they provided any coordinates for a starting-point. According to Ukraine, the starting-point should be to the east of the island at the point of intersection of the outer limits of both States' territorial seas ${ }^{42}$.

The Court carefully examined border agreements beginning with the 1948 Peace Treaty. Special attention was paid to the 2003 State Border Régime Treaty and Article 1 thereof, which was extensively quoted by the Court. The ICJ rejected the Romanian argument and noted that none of the agreements in question supported the starting-point (Point $\mathrm{X}$ ) to the east of Serpents' Island ${ }^{43}$. Therefore, it concluded that the starting-point, at which the delimitation should begin, was the point of intersection of the RomaniaUkraine territorial sea boundary (hereinafter referred to as "Point 1").

\subsection{Division of the Territorial Sea of Ukraine and the Continental Shelf and Exclusive Economic Zone of Romania}

Romania considered that the States had already agreed on the line dividing the territorial sea of Ukraine and the continental shelf and

41 Romania referred to this starting-point as "Point X". Memorial of Romania, at paras. 11.51-11.57. See: Counter-Memorial of Ukraine, chapter 5; Reply of Romania, chapter 4; Rejoinder of Ukraine, chapter 3.

42 Judgment, at paras. 50-55.

43 Ibid., at paras. 62-65. 
exclusive economic zone of Romania. The Court noted that paragraph 4 of Articles 74 and 83 provides that where there is an agreement in force between the States concerned, questions relating to the delimitation of the exclusive economic zone and the continental shelf „shall be determined in accordance with the provisions of that agreement" ${ }^{\text {. }}$ Romania relied on the 1949 instruments but the Court rightly observed that, at that time, the concept of an exclusive economic zone was still some long years away and the International Law Commission had yet to begin its work on the law of the sea which resulted in the 1958 Geneva Convention on the Continental Shelf. Moreover, the 1949 Agreement made no reference to the continental shelf and the exclusive economic zone, and the only agreement that dealt with these concepts was the 1997 Additional Protocol which contained a detailed provision on negotiating and establishing a maritime boundary between the adjacent States ${ }^{45}$. Furthermore, the USSR did not renounce - explicitly or impliedly - its right to waters beyond the territorial sea ${ }^{46}$. The establishing of the Soviet border in the 1949 instruments at the outer limit of the territorial sea of the island did not thereby constitute a renunciation of any entitlement to maritime areas beyond the territorial sea ${ }^{47}$. The Court could find no support for Romania in any agreement concerning the Romania-Ukraine border nor in the variety of maps presented by Romania which could evidence an estoppel or an understanding of the 1949 Agreement that would be favourable to Romania ${ }^{48}$. Thus the Court impliedly confirmed, at least to some extent, its stance on the boundary régimes established under the agreement between the States concerned. Both explicit and tacit (or de facto) agreements may constitute a new boundary regime. If a treaty on a maritime boundary exists, no difficulty should arise in proving a valid boundary régime. However, the case is different as regards tacit agreements. Whilst these also suffice to establish a boundary, the threshold for evidence is high. The Court has been firm on its stance regarding the establishment of a boundary under tacit agreements, and

44 Ibid., at para. 69.

45 Ibid., at para. 70.

46 Ibid., at para. 71.

47 Ibid., at para. 75.

48 See: Memorial of Romania, chapter 11. 
only compelling evidence presented by a party asserting the existence of such a boundary could convince the Court to acknowledge that the States concerned are bound by a tacit agreement. In one of its previous judgment it stated that „[e]vidence of a tacit legal agreement must be compelling. The establishment of a permanent maritime boundary is a matter of grave importance and agreement is not easily to be presumed" 49 .

The consistent jurisprudence of the ICJ points to the conclusion that a State which asserts the existence of a boundary on the basis of a tacit agreements must present clear and convincing evidence to prove the existence of a valid boundary régime. The presumption is that the States concerned have not established a boundary and therefore a State asserting such a boundary has to meet the high burden of proof ${ }^{50}$.

\section{Relevant Coasts}

Having decided the preliminary issues, the Court moved forward to determine two basic elements which are necessary for the sole purpose of delimiting maritime areas. In order to proceed with the maritime delimitation at the further stages of its established methodology, the ICJ had first to determine the relevant coasts and relevant maritime area. Both concepts are crucial for the determination of maritime claims and the drawing of a delimitation line. A coast is relevant for the purpose of delimitation if it generates projections which overlap with projections from a coast of the other State ${ }^{51}$. It is a well-recognized rule of maritime delimitation that the size of the continental shelf and exclusive economic zone depends upon the length of the relevant coasts of adjacent or opposite States. As the Court stated in 1982, "[t]he geographic correlation between coast and submerged areas off the coast is the basis of the coastal State's legal title" 52 . Maritime areas should correspond to the length of

49 Territorial and Maritime Dispute between Nicaragua and Honduras, supra note 13, at para. 253.

50 See: judgment, at para. 68, with the quoted ICJ case law.

51 Ibid., at para. 99.

52 Continental Shelf (Tunisia/Libyan Arab Jamahiriya), supra note 4, at para. 73. In Aegean Sea Continental Shelf, supra note 3, at para. 86, the Court noted that: „it is solely 
coastal lines of adjacent States and there can be no disproportionality between the continental shelf and the exclusive economic zone of Romania and Ukraine. On this score, the ICJ reaffirmed its previous decisions by saying that:

„[t]he title of a State to the continental shelf and to the exclusive economic zone is based on the principle that the land dominates the sea through the projection of the coasts or the coastal fronts. As the Court stated in the North Sea Continental Shelf (Federal Republic of Germany/Denmark; Federal Republic of Germany/Netherlands) cases, 'the land is the legal source of the power which a State may exercise over territorial extensions to seaward' (Judgment, I.C.J. Reports 1969, p. 51, para. 96). In the Continental Shelf (Tunisia/Libyan Arab Jamahiriya) case, the Court observed that 'the coast of the territory of the State is the decisive factor for title to submarine areas adjacent to it' (Judgment, I.C.J. Reports 1982, p. 61, para. 73"53).

Accordingly, it seems fair to say that the coast of the territory of a State accounts for its title to the continental shelf and the exclusive economic zone. The title to maritime areas stems from sovereignty over the land territory of a coastal State. The State exercises its sovereign rights and jurisdiction over territorial extensions in the seaward direction by virtue of its exclusive competence in regard to its own territory. The principle of territorial sovereignty operates in such a way as to make it the point of departure in settling most issues of international relations, including the questions of resolving overlapping claims by drawing a line of separation of the maritime areas between adjacent or opposite States ${ }^{54}$. Consequently, it might be said that State sovereignty, through the adjacency of maritime area to the territory of State, constitutes the title to the continental shelf and the exclusive economic zone ${ }^{55}$.

by virtue of the coastal State's sovereignty over the land that rights of exploration and exploitation in the continental shelf can attach to it, ipso jure, under international law. In short, continental shelf rights are legally both an emanation from and an automatic adjunct of the territorial sovereignty of the coastal State."

53 Judgment, at para. 77.

54 See: Island of Palmas Case, supra note 23, at p. 838.

55 As P. Weil has stated, it is not: "the physical fact of adjecency of the sea areas to the shore which creates title or constitutes the legal basis for it. It is by virtue of the law that one of the attributes of a State is the power to generate, through the medium 
At the end of its general considerations, the Court referred to the role of relevant coasts in the delimitation process. According to the ICJ, they can have two closely related legal aspects. First, the identification of relevant coasts is necessary for the determination of the overlapping claims to maritime zones. Secondly, relevant coasts are needed in the third and final stage of the delimitation process, in order to ascertain whether "any disproportionality exists in the ratios of the coastal length of each State and the maritime areas falling either side of the delimitation line"56. There may be no significant disproportionality of maritime areas, since it may lead to an inequitable result ${ }^{57}$.

Having briefly set out the position of the States, the Court determined the relevant coasts of Romania and Ukraine. The length of the relevant Romanian coast was approximately $248 \mathrm{~km}$, whereas the length of the relevant Ukrainian coast was approximately $705 \mathrm{~km}$, even though Ukraine had claimed a total length of 1,058 km. The Court could not accept Ukraine's contention that the coasts of Karkinits'ka Gulf form part of the relevant coast ${ }^{58}$. The coasts of the Gulf face each other and do not project in the area to be delimited by the ICJ. Moreover, the coasts of the Gulf do not overlap with the extensions of Romania's coasts. Consequently, the Court excluded the coasts of Karkinits'ka Gulf from its further consideration ${ }^{59}$. Thus, the ICJ confirmed its previous case-law in the field of maritime delimitation in which it stated that "the submarine extension of any part of the coast of one Party which, because of its geographic situation, cannot overlap with the extension of the coast of the other, is to be excluded from further consideration by the Court" 60 .

of its coastline, title to maritime areas adjacent to its coasts, and it is only 'legally' that maritime rights have been defined by the Court as an emanation and adjunct of State sovereignty"; P. Weil, The Law of Maritime Delimitation - Reflections, translated from French by M. MacGlashan, Grotius Publications Limited, Cambridge, 1989, at pp. 55-56.

56 Judgment, at para. 78.

57 See: judgment, at para. 210; Bay of Bengal, at para. 240.

58 See: sketch-maps, Judgment, at pp. 91 (the Romanian claims), 92 (the Ukrainian claims), 94 (the relevant coasts identified by the ICJ).

59 Ibid., at para. 100. For the same reason, the coastline of Yahorlyts'ka Gulf and Dnieper Firth were also excluded from the delimitation process.

60 Continental Shelf (Tunisia/Libyan Arab Jamahiriya), supra note 4, at para. 75. 


\section{Relevant Maritime Arrea}

The determination of relevant coasts allows for the determination of a relevant maritime area. Similarly to relevant coasts, the relevant maritime area plays a two-fold role in the methodology of maritime delimitation. Firstly, it may include certain maritime spaces for the purpose of the delimitation process and exclude others which are not germane to the case at hand. However, for the purposes of the delimitation process, calculation of the relevant area need not be precise and may be approximate. The Court once again underlined that the object of delimitation was to achieve a delimitation that is equitable, not an equal apportionment of maritime areas ${ }^{61}$. Secondly, relevant maritime areas are also pertinent at the final stage of the delimitation process insofar as checking for disproportionality ${ }^{62}$. The test of disproportionality is not a method of delimitation, it rather serves for the purpose of

"checking whether the delimitation line arrived at by other means needs adjustment because of a significant disproportionality in the ratios between the maritime areas which would fall to one party or other by virtue of the delimitation line arrived at by other means, and the lengths of their respective coasts ${ }^{63}$.

In determining the relevant maritime areas, the Court divided them into two parts. The area in the north encompassed the section starting approximately from the mouth of the Nistru/Dniestr River (Point S) to Cape Tarkhankut, since the Ukrainian coast in the north was a relevant coast for the purpose of the delimitation exercise. As regards the southern part, the Court took into account all the disputed areas (the southwestern and south-eastern triangles), since in both of these areas the maritime claims of Romania and Ukraine overlapped. The ICJ underlined

61 Judgment, at para. 111. The ICJ referred at the same time to its jurisprudence: North Sea Continental Shelf case, supra note 2, at para. 18; Maritime Delimitation in the Area between Greenland and Jan Mayen, supra note 8, at para. 64.

62 Judgment, at para. 110.

63 Ibid., at para. 110. 
that its decision in no way prejudiced the position of any third State regarding its entitlements in the Black Sea ${ }^{64}$.

\section{Delimitation Methodology}

In ascertaining the delimitation methodology the Court invoked its settled jurisprudence to point out that the methodology consists of three separate and defined stages. The Court relied on the Continental Shelf (Libyan Arab Jamahiriya/Malta) case, in which it tersely explained the separate steps of the delimitation process ${ }^{65}$. However, the 2009 judgment was the first case in which the ICJ fully described the three stages of the delimitation methodology. According to the Court, the first stage relates to the establishment of a provisional delimitation line. Further, the ICJ takes into account the requirements derived from other factors (relevant circumstances), calling for the adjustment or shifting of the provisional line in order to achieve an equitable result. The third and final stage is devoted to verification of the line, so as to check whether it leads to an inequitable result by reason of any marked disproportion. At this stage the Court examines the ratios of the respective coastal length to the ratio of the relevant maritime area of adjacent or opposite States. For the sake of convenience, both the theory of delimitation process and its application in Black Sea case may be presented in the order which reflects the general position of the ICJ with respect to each stage of the delimitation process.

\subsection{The First Stage - Provisional Equidistance Line}

\subsubsection{The General Observations}

The delimitation process starts with the establishment of a provisional delimitation line. The Court applies methods that are geometrically

64 Ibid., at paras. 113-114. On the position of the third States see: J.-G. Mahinga, supra note 24, at pp. 1168-1170.

65 Continental Shelf (Libyan Arab Jamahiriya/Malta), supra note 5, at para. 60. See also: Land and Maritime Boundary between Cameroon and Nigeria, supra note 11, at paras. 288--290; Dispute concerning Delimitation of the Maritime Boundary between Bangladesh and Myanmar in the Bay of Bengal, supra note 16, at paras. 229-233. 
objective and appropriate for the geography of the area concerned. An equidistance line is drawn between adjacent coasts and a median line between opposite coasts. No legal consequences follow from the use of the above terms ${ }^{66}$.

\subsubsection{Base points}

The initial step in drawing equidistance and median lines is to establish coastal points from which those lines are to be construed (base points). The Court uses the most appropriate points on the coasts of the States concerned, which are subsequently employed for drawing equidistance and median lines. In selecting the relevant base points the Court takes into consideration not only the choice of base points made by one of the adjacent or opposite States, but also the physical geography of the relevant coasts. Therefore, particular attention is paid to protuberant coastal points which are situated nearest to the delimitation area ${ }^{67}$. It may be fair to say that both base points and a provisional equidistance line are different in each case, since their location largely depends upon the geography of the region concerned. Especially, a significant impact on both elements is had by one aspect of the geography of relevant coasts, to wit, whether the relevant coast is adjacent or opposite. Furthermore, the ICJ pointed out that:

"the issue of determining the baseline for the purpose of measuring the breadth of the continental shelf and the exclusive economic zone and the issue of identifying base points for drawing an equidistance/median line for the purpose of delimiting the continental shelf and the exclusive economic zone between adjacent/opposite States are two different issues" ${ }^{\text {" }}$.

66 Judgment, at para. 116.

67 Ibid., at paras. 117, 135.

68 Ibid., at para. 137. The Court explained it as follows: "[i]n the first case, the coastal State, in conformity with the provisions of UNCLOS (Articles 7, 9, 10, 12 and 15), may determine the relevant base points. It is nevertheless an exercise which has always an international aspect ... In the second case, the delimitation of the maritime areas involving two or more States, the Court should not base itself solely on the choice of base points made by one of those Parties. The Court must, when delimiting the continental shelf and exclusive economic zones, select base points by reference to the physical geography of the relevant coasts". 
Thus, it underlined the dual function of base points ${ }^{69}$. In this context, it should also be noted that a coastal State has exclusive competence to delimit its maritime areas, but the validity of such delimitation with regard to other States depends upon international law ${ }^{70}$.

Having in mind the fact that the Ukrainian coast consists of two portions (one adjacent to the Romanian coast and one opposite thereto), the Court decided to define base points separately for the adjacent coasts and for the opposite coasts. The next step was to identify a turning-point on the equidistance line "where the effects of adjacency give way to those of the coasts on the opposite side, resulting in a change in the direction of the line"71. Finally, the Court considered whether Serpents' Island had any relevance for the choice of base points.

In the first place, the Court chose the base points on the Romanian coasts. It decided to use the Sacalin Peninsula, which is opposite the Ukrainian coasts, and the landward end of the Sulina dyke, which is adjacent to the Ukrainian coasts ${ }^{72}$. The Court chose the landward and seaward end of the dyke since "it has the advantage ... of not giving greater importance to an installation than to the physical geography of the landmass"73. In this respect, it seems that the ICJ underscored its

69 See also: Continental Shelf (Libyan Arab Jamahiriya/Malta), supra note 5, at para. 64. See: P. Weil, À propos de la double fonction des lignes et points de base dans le droit de la mer, [in:] E. G. Bello, B. A. Ajibola (eds), 'Essays in honour of judge Taslim Olawale Elias’, Martinus Nijhoff, Dordrecht 1992, Vol. I, at pp. 145-162; J.-G. Mahinga, supra note 24 , at pp. 1172-1175.

70 Fisheries, supra note 2, at p. 132.

71 Ibid., at para. 127.

72 Ibid., at paras. 129-141. As regards the Sacalin Peninsula, the Court rejected the Ukrainian contention that it is a spit of sand (See: Counter-Memorial of Ukraine, at paras. 3.50, 3.57, 4.26; Rejoinder of Ukraine, at paras. 4.5, 4.51). According to the Court, "[t]he geomorphological features of the peninsula and its possibly sandy nature have no bearing on the elements of its physical geography which are relevant for maritime delimitation. The geographical circumstances are the following: the peninsula belongs to the landmass, it forms part of the Romanian mainland, its' permanent uncovering at high tide is not contested". Judgment, at para. 129.

73 Ibid., at para. 129. The Court furthermore noted that no convincing evidence has been presented that this dyke serves any direct purpose in port activities. Therefore, the seaward end of the dyke could not be regarded as "the outermost permanent harbour works which form an integral part of the harbor system" within the meaning of Article 11 of UNCLOS. 
preference for physical circumstances over human actions which artificially change the geography of a coast $^{74}$.

As regards the Ukrainian base points the Court concluded that, in the sector of adjacent coasts, it would use the south-eastern tip of Tsyganka Island. It disregarded the island of Kubansky for the purposes of the delimitation $^{75}$. On the other side, Cape Tarkhankut and Cape Khersones were determined as the base points on the opposite Ukrainian coasts.

Finally, the Court considered the relevance of Serpents' Island for the determination of base points. Ukraine contended that Serpents' Island was an island and not a rock as that term is understood in Article 121(3) of UNCLOS. According to the respondent State, it is not "just an uninhabited and uninhabitable feature, but is very much an island with appropriate buildings and accommodation for an active population"76. Ukraine relied on Article 121(2) of UNCLOS which stipulates that the territorial sea, the contiguous zone, the exclusive economic zone and the continental shelf of an island are determined in accordance with the provisions of the UNCLOS applicable to other land territory ${ }^{77}$. Conversely, Romania argued that Serpents' Island was not entitled to exclusive economic zone or continental shelf because it is a very small rocky island which cannot sustain human habitation or an economic life of its own. Therefore, Article 121(3) of UNCLOS was applicable to the island ${ }^{78}$. Moreover, Serpents' Island may not sustain human habitation or economic life of its own and, accordingly, constitutes a rock within the meaning of Article 121(3) of UNCLOS ${ }^{79}$.

The review of international case law shows that no general rule exists with respect to the effect to be given to an island in the maritime

74 See: J.-G. Mahinga, supra note 24, at pp. 1180-1182.

75 See: Judgment, at para. 144.

76 Counter-Memorial of Ukraine, at para. 7.37.

77 Ukraine referred to Maritime Delimitation and Territorial Questions between Qatar and Bahrain, I.C.J Reports 2001, at para. 185, in which the ICJ stated that: "[i]n accordance with Article 121(2), of the 1982 Convention on the Law of the Sea, which reflects customary international law, islands, regardless of their size, in this respect enjoy the same status, and therefore generate the same maritime rights, as other land territory".

78 Reply of Romania, at para. 5.13.

79 Ibid., at paras. 5.16-5.19, 5.27-5.107. 
delimitation of the exclusive economic zone and continental shelf. The effect depends on the geographic realities and circumstances of each specific case. Thus, each case is unique and demands specific treatment and "the ultimate goal" is to "reach a solution that is equitable" 80 . In the context of the present case, the ICJ decided to evade directly answering the question put by the parties and did not refer to Article 121 of UNCLOS, but instead invoked geographical considerations and previous case law on the subject. The ICJ highlighted the fact that Serpents' Island was a single island as opposed to a cluster of fringe islands. A single island cannot change the geography of the delimitation area. The Court stated that:

"[t]o count Serpents' Island as a relevant part of the coast would amount to grafting an extraneous element onto Ukraine's coastline; the consequence would be a judicial refashioning of geography, which neither the law nor practice of maritime delimitation authorizes" $"$.

The Court referred to its previous decision concerning the islet of Filfla, an inhabited rock belonging to the republic of Malta ${ }^{82}$. The Court found that it was equitable to disregard Filfla when calculating the provisional median line between Malta and Libya ${ }^{83}$. It might be reasonably assumed that the Court was of the opinion that drawing base points on Serpents' Island would be inequitable as it would cause

80 Delimitation of the Maritime Boundary in the Gulf of Maine Area, supra note 6, at para. 81; Dispute concerning Delimitation of the Maritime Boundary between Bangladesh and Myanmar in the Bay of Bengal, supra note 16, at para. 317.

81 Judgment, at para. 149. Similarly, in the Bay of Bengal case, supra note 16, at para. 318, the ITLOS decided that St. Martin's Island could not be given any effect, since it "would result in a line blocking the seaward projection from Myanmar's coast in a manner that would cause an unwarranted distortion of the delimitation line".

82 Continental Shelf (Libyan Arab Jamahiriya/Malta), supra note 5, at para. 64. The principle which prohibits the judicial refashioning of geography was enunciated for the first time in the North Sea case, supra note 2, at para. 91. See also: Delimitation of the Maritime Boundary in the Gulf of Maine Area, supra note 6, at para. 37; Territorial and Maritime Dispute between Nicaragua and Honduras, supra note 13, at para. 289.

83 The Court referred in 1985 to its judgment in the North Continental Shelf cases, supra note 2, to stress that "the equitableness of an equidistance line depends on whether the precaution is taken of eliminating the disproportionate effect of certain "islets, rocks and minor coastal projections". 
disproportionate effects which "neither the law nor practice of maritime delimitation authorizes". Thus, proportionality is an equitable principle in the law of maritime delimitation. In the case of islands, the effect of delimitation is proportionate and, consequently, equitable, only if there is a cluster of fringe islands which may be considered as part of a State's coast. In this context, the Court referred to the case between Eritrea and Yemen in which the Arbitral Tribunal placed base points lying on the low water line of certain fringe islands (the Dahlaks islands) considered to constitute part of the very coastline of Eritrea ${ }^{84}$. Serpents' Island lies alone, some 20 nautical miles away from the mainland, and thus the Court rightly considered it inappropriate to select any base point on the island.

\subsubsection{Construction of the Provisional Equidistance Line}

Having established the base points, the Court went on to determine the provisional equidistance line $e^{85}$. The initial segment of the line was calculated with reference to the base points of the adjacent coasts. The ICJ used the base points located on the landward end of the Sulina dyke on the Romanian coast and south-eastern tip of Tsyganka Island on the Ukrainian coast to draw the line in a south-eastern direction to Point A. The further segment of the line was affected by the base point located on the Sacalin Peninsula on the Romanian coast which slightly altered the direction of the line to Point B. At Point B, the line became affected by the base point located on Cape Tarkhankut on Ukraine's opposite coasts and thus turned south-east and continued to Point $C$, which was calculated by using the base points on the Sacalin Peninsula on the Romanian coast and Capes Tarkhankut and Khersones on the Ukrainian coast. From Point $C$ the provisional equidistance line runs in a southerly direction until the maritime zones of third States.

84 Award of the Arbitral Tribunal in the Second Stage of the Proceedings between Eritrea and Yemen, supra note 15, at paras. 139-146. It also needs to be stressed that - as opposed to Seprents' Island - the larger islands among the Dahlaks have a considerable population. Therefore the arbitral tribunal decided that it was a typical example of a group of islands that formed an integral part of the general coastal configuration.

85 See: Sketch-map No. 6: Construction of the provisional equidistance line, Judgment, at p. 114, at paras. 153-154. 


\subsection{The Second Stage - Relevant Circumstances}

The second stage of the delimitation process consists of considering whether there exist any factors calling for the adjustment or shifting of the provisional equidistance line in order to achieve an equitable result as required by Articles 74(1) and 83(1) of UNCLOS ${ }^{86}$. The purpose of that stage is to ensure that geometry does not prevail over equity, which is the fundamental norm of the law of maritime delimitation ${ }^{87}$. The Court stressed this point by saying that:

"[t]heir [relevant circumstances] function is to verify that the provisional equidistance line, drawn by the geometrical method from the determined base points on the coasts of the Parties is not, in light of the particular circumstances of the case, perceived as inequitable" ${ }^{m 8}$.

The concept of relevant circumstances may "be described as a fact necessary to be taken into account in the delimitation process" 89 . It must be noted that Article 6 of the 1958 Geneva Convention on the Continental Shelf refers to special circumstances. The thesis advanced in this article is that there is no valid distinction between special circumstances under Article 6 and relevant circumstances in customary international law and

86 Ibid., at paras. 120-121, 155. See: Dispute concerning Delimitation of the Maritime Boundary between Bangladesh and Myanmar in the Bay of Bengal, supra note 16, at para. 275.

87 In Continental Shelf (Libyan Arab Jamahiriya/Malta), supra note 5, at para. 62, the ICJ observed that: "[q]uestions arise only in the assessment of the impact of distance considerations on the actual delimiting. In this assessment, account must be taken of the fact that, according to the "fundamental norm" of the law of delimitation, an equitable result must be achieved on the basis of the application of equitable principles to the relevant circumstances. It is therefore necessary to examine the equities of the distance criterion and of the results to which its application may lead".

See also: Memorial of Canada, at para. 278; Counter-Memorial of USA, at para. 123, Delimitation of the Maritime Boundary in the Gulf of Maine Area (Canada/United States of America), I.C.J. Pleadings, Oral Arguments, Documents 1984, Vol. IV.

88 Judgment, at para. 155.

89 Maritime Delimitation in the Area between Greenland and Jan Mayen, supra note 8 , at para. 55 . 
$\mathrm{UNCLOS}^{90}$. To this end it should be emphasised that, according to the Arbitral Tribunal, the two categories: "reflect differences of approach and terminology rather than of substance" 91 . It observed that "the role of the 'special circumstances' condition in Article 6 is to ensure an equitable delimitation" ${ }^{\prime 2}$. Articles $74(1)$ and $83(1)$ of UNCLOS aim at the delimitation of the continental shelf and exclusive economic zone which achieves an equitable solution. Article 6 was drafted to ensure that "failing agreement, the boundary between States abutting on the same continental shelf is to be determined on equitable principles"93. The same function is set forth in Articles 74(1) and 83(1). Therefore, both terms ("special circumstances" and "relevant circumstances") may be used interchangeably with no attempt to differentiate between them.

Relevant circumstances constitute an open-ended category ${ }^{94}$ and comprise an undefined set of factors. The factors which may be considered as relevant circumstances have not been exhaustively listed in any documents and they are considered on a case-by-case basis. Therefore, there is no legal limit as to factors which could be covered by relevant circumstances. It seems that they are constrained only by the object of maritime delimitation, which seeks an equitable solution. France, arguing in the Anglo-French Continental Shelf case, referred to this observation as "plurality of methods, unity of aim" ${ }^{95}$. Moreover, there is no hierarchy between those factors. The ICJ rightly observed in the North Continental Shelf cases that:

90 M. D. Evans, Maritime Delimitation and Expanding Categories of relevant Circumstances, 'International \& Comparative Law Quarterly' 1991, Vol. 40, at p. 2. See: Maritime Delimitation in the Area between Greenland and Jan Mayen, supra note 8, at para. 56, where the Court stated that: "[a]lthough it is a matter of categories which are different in origin and in name, there is inevitably a tendency towards assimilation between the special circumstances of Article 6 of the 1958 Convention [on the Continental Shelf] and the relevant circumstances under customary law, and this if only because they both are intended to enable the achievement of an equitable result".

91 Anglo-French Continental Shelf Case, supra note 15, at para. 148.

92 Ibid., at para. 70 .

93 Ibid., at para. 70.

94 M. D. Evans, supra note 90, at p. 3 and pp. 17-26, where M. D. Evans discusses the limits on "open-endedness".

95 Anglo-French Continental Shelf Case, supra note 15, at para. 83. 
"[i]n fact, there is no legal limit to the considerations which States may take account of for the purpose of making sure that they apply equitable procedures, and more often than not it is the balancing-up of all such considerations that will produce this result rather than reliance on one to the exclusion of al1 others. The problem of the relative weight to be accorded to different considerations naturally varies with the circumstances of the case" ${ }^{\prime 6}$.

There are an unlimited number of factors (categories which could be considered as relevant circumstances), the roots of which are derived from various facts. All such factors vary from case to case. The Arbitral Tribunal has described the application of relevant circumstances in the following way:

"[t]he factors and methods ... result from legal rules, although they evolve from physical, mathematical, historical, political, economic or other facts. However, they are not restricted in number and none of them is obligatory for the Tribunal, since each case of delimitation is a unicum ${ }^{97}$ ... Where factors are concerned, the Tribunal must list them and assess them. They result from the circumstances of each particular case and, in particular, from characteristics peculiar to the region. These circumstances will be taken into consideration only when the Tribunal considers them relevant to the case in point. These circumstances are varied and are not restricted to physical facts whether geographical, geological or geomorphological"98.

The jurisprudence of the ICJ, supported by arbitral awards, has discussed a number of factors frequently invoked by States. All of these may be divided into two groups: geographical and non-geographical categories $^{99}$.

96 North Sea Continental Shelf, supra note 2, at para. 93.

97 In Delimitation of the Maritime Boundary in the Gulf of Maine Area, supra note 6 , at para. 81 , the ICJ stated with respect the equitable criteria that: "each specific case is, in the final analysis, different from all the others".

98 Delimitation of the Maritime Boundary between Guinea and Guinea-Bissau, supra note 15 , at paras. 89 [italics in the original].

99 The Arbitral Tribunal in Anglo-French Continental Shelf Case, supra note 15, at para. 97 , referred to „the geographic and other relevant circumstances of each particular case”. 
Geographical factors may be defined as "the general configuration of the coasts of the Parties, as well as the presence of any special or unusual features"100, or as the general configuration of the region as a whole ${ }^{101}$. This group may covers the geographical configuration of coasts, islands ${ }^{102}$, low-tide elevations ${ }^{103}$, a sizeable maritime feature ${ }^{104}$, the existence of segments of coasts which are not relevant ${ }^{105}$, mud flats, sand cays ${ }^{106}$, coastal irregularities ${ }^{107}$, concavity of a gulf ${ }^{108}$, geological and

However, it should be noted that the Chamber of the Court in the Delimitation of the Maritime Boundary in the Gulf of Maine Area, supra note 6, at para. 59, took a narrow definition of relevant circumstances limiting them to geographic categories as it was convinced that: "for the purposes of such a delimitation operation as is here required, international law, as will be shown below, does no more than lay down in general that equitable criteria are to be applied, criteria which are not spelled out but which are essentially to be determined in relation to what may be properly called the geographical features of the area".

See also: J. Symonides, Delimitacja obszarów morskich na Marzu Barentsa i Oceanie Arktycznym między Rosja i Norwegiq [Delimitation of maritime areas in the Barents Sea and the Arctic Ocean between Russia and Norway], [in:] U. Jackowiak et al., (ed.), 'Współczesne problemy prawa. Księga Pamiątkowa dedykowana Profesorowi Jerzemu Młynarczykowi' [Contemporary Issues of Law. Essays in Honour of Professor Jerzy Młynarczyk], Wyższa Szkoła Administracji i Biznesu, Gdynia 2011, at p. 57, at pp. 66-70.

100 North Sea Continental Shelf, supra note 2, at para. 101(D)(1).

101 Delimitation of the Maritime Boundary between Guinea and Guinea-Bissau, supra note 15 , at paras. $108-109$.

102 Continental Shelf (Tunisia/Libyan Arab Jamahiriya), supra note 4, at para. 76; Maritime Delimitation in the Area between Greenland and Jan Mayen, supra note 8, at para. 60; Delimitation of the Maritime Boundary between Guinea and Guinea-Bissau, supra note 15, at para. 95; Maritime Delimitation and Territorial Questions between Qatar and Bahrain, supra note 10, at paras. 218-219; Land and Maritime Boundary between Cameroon and Nigeria, supra note 11, at paras. 298-299.

103 Continental Shelf (Tunisia/Libyan Arab Jamahiriya), supra note 4, at para. 79.

104 Maritime Delimitation and Territorial Questions between Qatar and Bahrain, supra note 10 , at paras. $245-248$.

105 Continental Shelf (Tunisia/Libyan Arab Jamahiriya), supra note 4, at para. 77.

106 See: M. D. Evans, supra note 90, at p. 5.

107 North Sea Continental Shelf, supra note 2, at para. 89.

108 Land and Maritime Boundary between Cameroon and Nigeria, supra note 11, at paras. 296-298; Dispute concerning Delimitation of the Maritime Boundary between Bangladesh and Myanmar in the Bay of Bengal, supra note 16, at paras. 290-297. 
morphological factors ${ }^{109}$. The category of landmass behind the coast as a relevant circumstance was rejected by the Court ${ }^{110}$.

Non-geographical factors include oil platforms (oil practice) ${ }^{111}$, defence, military and security interests ${ }^{112}$, economic interests ${ }^{113}$, navigational factors ${ }^{114}$, fisheries ${ }^{115}$, historical factors ${ }^{116}$, population, socio-

109 Anglo-French Continental Shelf Case, supra note 15, at paras. 83, 198; Continental Shelf (Tunisia/Libyan Arab Jamahiriya), supra note 4, at paras. 76-77.

110 Continental Shelf (Libyan Arab Jamahiriya/Malta), supra note 5, at para. 49. See: Delimitation of the Maritime Boundary between Guinea and Guinea-Bissau, supra note 15, at paras. $119-120$.

111 Land and Maritime Boundary between Cameroon and Nigeria, supra note 11, at paras. 302-304.

112 Anglo-French Continental Shelf Case, supra note 15, at paras. 161-162; Continental Shelf (Libyan Arab Jamahiriya/Malta), supra note 5, at paras. 50-51; Maritime Delimitation in the Area between Greenland and Jan Mayen, supra note 8, at para. 81; Award of the Arbitral Tribunal in the Second Stage of the Proceedings between Eritrea and Yemen, supra note 15, at para. 21.

113 Anglo-French Continental Shelf Case, supra note 15, at para. 162; Continental Shelf (Tunisia/Libyan Arab Jamahiriya), supra note 4, at para. 76; Continental Shelf (Libyan Arab Jamahiriya/Malta), supra note 5, at para. 50. In Delimitation of the Maritime Boundary between Guinea and Guinea-Bissau, supra note 15, at para. 123, the Tribunal observed that it "does not have a power to compensate for the economic inequalities of the States concerned by modifying a delimitation which it considers is called for by objective and certain considerations ... The Tribunal can nevertheless not completely loose sight of the legitimate claims by virtue of which economic circumstances are invoked, not contest the right of the peoples concerned to a level of economic and social developments which fully preserves their dignity".

114 Anglo-French Continental Shelf Case, supra note 15, at paras. 162-163.

115 Delimitation of the Maritime Boundary in the Gulf of Maine Area, supra note 6, at paras. 233-234; Award of the Arbitral Tribunal in the Second Stage of the Proceedings between Eritrea and Yemen, supra note 15, at paras. 20, 52-71; Maritime Delimitation in the Area between Greenland and Jan Mayen, supra note 8, at paras. 73-76.

116 Continental Shelf (Tunisia/Libyan Arab Jamahiriya), supra note 4, at paras. 76, 81, 105. Delimitation of the Maritime Boundary in the Gulf of Maine Area, supra note 6, at para. 233. In Maritime Delimitation and Territorial Questions between Qatar and Bahrain, supra note 10, at paras. 237-240, Qatar invoked to draw the single maritime boundary "with due regard to the line dividing the seabed of the two States as described in the British decision of 23.12.1947", since it constituted a special circumstance. The Court dismissed that argument. 
economic and cultural factors ${ }^{117}$, environmental factors ${ }^{118}$, the existence of actual or prospective delimitations with third States in the region ${ }^{119}$, the existence of legislative acts of riparian States relating to fishing, the maritime zones and petroleum concessions ${ }^{120}$, the existence of natural resources, including petroleum fields or wells within the relevant area ${ }^{121}$ (also pearling banks) ${ }^{122}$, the presence of ice in the waters of the region ${ }^{123}$ and the conduct of the Parties concerning the relevant area ${ }^{124}$. Moreover, the political status of independent State seems also to be, at least to some extent, a relevant circumstance ${ }^{125}$. All relevant circumstances must be weighed cumulatively in order to achieve an equitable solution.

In the case at hand, Romania invoked virtually no specific relevant circumstances and argued that its provisional equidistance line had already presented the equitable result ${ }^{126}$. Conversely, Ukraine referred to several circumstances which it considered called for an adjustment of the provisional equidistance line $e^{127}$. Each of these will be dealt with below under separate headings. Before discussing each relevant circumstance raised by Ukraine, the Court rightly observed that its provisional equidistance line did not coincide with the lines drawn by both States and the Court's line would be further considered when analysing the parties' contentions ${ }^{128}$.

117 Maritime Delimitation in the Area between Greenland and Jan Mayen, supra note 8 , at paras. $79-80$.

118 Delimitation of the Maritime Boundary in the Gulf of Maine Area, supra note 6, at para. 54 .

119 Continental Shelf (Tunisia/Libyan Arab Jamahiriya), supra note 4, at para. 77.

120 Ibid., at para. 77.

121 North Sea Continental Shelf, supra note 2, at para. 101(D)(2); Continental Shelf (Tunisia/Libyan Arab Jamahiriya), supra note 4, at para. 77; Continental Shelf (Libyan Arab Jamahiriya/Malta), supra note 5, at para. 50; Maritime Delimitation in the Area between Greenland and Jan Mayen, supra note 8, at para. 72.

122 Maritime Delimitation and Territorial Questions between Qatar and Bahrain, supra note 10 , at paras. 235-236.

123 Maritime Delimitation in the Area between Greenland and Jan Mayen, supra note 8, at paras. 77-78.

124 Ibid., at paras. 82-86.

125 Continental Shelf (Libyan Arab Jamahiriya/Malta), supra note 5, at para. 72.

126 Judgment, at para. 156. Reply of Romania, Chapter 6, at para. 8.29. But see: Section 7.2.2 below.

127 Counter-Memorial of Ukraine, Chapter 8; Rejoinder of Ukraine, Chapter 6.

128 Judgment, at para. 157. 


\subsubsection{Disproportion between Length of Coasts}

Ukraine asserted that a disparity existed between the length of the States' coasts and that the provisional equidistance line should be adjusted by moving it closer to the Romanian coast ${ }^{129}$. Romania rejected that argument and contended that the respective length of the relevant coasts of the States did not constitute relevant circumstances ${ }^{130}$. According to Romania, proportionality could be taken into account "only after having identified the line resulting from the application of the equitable principles/special circumstances approach"131, and, at any rate, the disparity between coastal length should not be considered as a relevant circumstance. Ukraine emphasized that its relevant coast was more than four times longer than the coast of Romania ${ }^{132}$. Accordingly, such disproportion was a relevant circumstance which should be taken into account at the second stage of the delimitation process.

To start with, the Court recalled two principles governing maritime delimitation:

1. the respective length of coasts can play no role in identifying the equidistance line which has been provisionally established. Therefore, proportionality as such does not bear on the initial establishment of the provisional equidistance line (first stage);

2. delimitation is a function (process) which is different from the apportionment of resources or areas ${ }^{133}$.

Thus, the Court concluded that: "[w] here disparities in the lengths of coasts are particularly marked, the Court may choose to treat that fact of geography as a relevant circumstance that would require some adjustments to the provisional equidistance line to be made"134. The

129 See: Rejoinder of Ukraine, at para. 6.37.

130 Reply of Romania, at para. 6.12.

131 Ibid., at para. 6.12; Judgment, at para. 160.

132 Ukraine calculated that "the coast of Ukraine fronting the relevant area measures some 1,058 kilometres while the coast of Romania measures only some 258 kilometres. As Ukraine has pointed out, this represents a difference in coastal lengths in the range of 4.1 to 1 in favour of Ukraine." Rejoinder of Ukraine, at para. 6.51.

133 Judgment, at para. 163; See: North Sea Continental Shelf, supra note 2, at para. 18.

134 Judgment, at para. 164. [italics added by the author]. See also: North Sea Continental Shelf, supra note 2, para. 101(D)(3); Maritime Delimitation in the Area between Greenland and Jan Mayen, supra note 8, at paras. 61-71. 
Court employed the word "may" which suggests that the ICJ is not under an obligation to take into account any possible disparity between the length of States' coasts. The reasoning of the Court and, especially, the quotations from the previous cases lead to the conclusion that only substantial disproportion (difference) constitutes a relevant circumstance calling for an equitable correction. However, even such an assumption is not fully convincing and persuasive in light of the language used in the present judgment and previous decisions of the Court. There are two arguments which support this submission.

First, the Court quoted its decision in the Cameron v. Nigeria case in which it acknowledged that „a substantial difference in the lengths of the parties' respective coastlines may be a factor to be taken into consideration in order to adjust or shift the provisional delimitation line"135. The Court underlined the possibility of taking into consideration disproportion of respective coastlines only if the difference is substantial. A contrario, it should be assumed that a non-substantial disparity may not be regarded as a relevant circumstance. The criterion of substantiality may be understood as a considerable difference "so great as to justify the adjustment" ${ }^{36}$. In the present case, the ratio amount to $4: 1$ in favour of Ukraine. According to the Court, such a difference is of course unquestionable, but is not substantial ${ }^{137}$. Furthermore, the Court underlined that a good portion of the Ukrainian coast projected "into the same area as other segments of Ukrainian coast, thus strengthening, but not spatially expanding the Ukrainian entitlement"138. Thus, the overlapping of the entitlement to the maritime zones weakened the overall tone of the ratio 4 to 1 in terms of the criterion of substantiality. In order to be more precise in respect of substantiality, the rule would appear to be that only a disparity of more

135 Land and Maritime Boundary between Cameroon and Nigeria, supra note 11, at para. 301. [emphasis added by the Court in the present judgment].

136 Continental Shelf (Libyan Arab Jamahiriya/Malta), supra note 5, at para. 68. The difference in coastal lengths between Malta and Libya was in ratio 8 to 1 in favour of Libya. In Maritime Delimitation in the Area between Greenland and Jan Mayen, supra note 8 , at para. 69 , the Court stated that the disparity between the lengths of coasts of Jan Mayen and Greenland (ratio approximately 1 to 9) called for adjustment or shifting of line by moving it closer to the coasts of Jan Mayen.

137 Judgment, at para. 168.

138 Ibid., at para. 168. 
that $4: 1$ or $5: 1$ may be regarded as substantial by the ICJ provided that the coastal areas of a State would not project into other relevant areas of that State. Such an understanding of a substantial difference is strongly supported by the case law of the Court.

\subsubsection{The Enclosed Nature of the Black Sea and the Delimitations Already Effected in the Region}

According to Romania, the enclosed nature of the Black Sea is a relevant circumstance as part of the wider requirement to take into account the geographical context of the area to be delimited ${ }^{139}$. Moreover, the geographical factor should be considered with any preexisting delimitation agreements in order not to dramatically depart from the method (the equidistance line) previously used in the Black Sea delimitation by other riparian States. The Court identified two agreements concerning the delimitation of the Black Sea, namely, the 1978 Agreement between Turkey and USSR and the 1997 Agreement between Bulgaria and Turkey. Ukraine contested the Romanian argument arguing that there was "no support in law or in the factual context"140. According to Ukraine, there is no special régime governing delimitation in an enclosed sea and bilateral agreements cannot affect the rights of third States.

The Court pointed out that it had already applied the equidistance line at the first stage of the delimitation process. Further, it decided that it would bear in mind the delimitation agreement when considering the endpoint of the single maritime boundary in the present case. Thus, the ICJ decided that no adjustment to the equidistance line as provisionally drawn was called for.

\subsubsection{The Presence of Serpents' Island in the Area of Delimitation}

The most crucial point, fiercely debated by the parties, was the proper characterization of Serpents' Island and its role in the delimitation of the States' maritime zones. The Court decided that the island had no impact on the delimitation of the continental shelf and the exclusive

139 Memorial of Romania, Chapter 6; Reply of Romania, at paras. 6.37-6.50; Judgment, at para. 169.

140 Maritime Delimitation in the Black Sea (Romania v. Ukraine), Verbatim Records, CR 2008/28, at p. 55 et seq., where the Ukrainian argument is completely presented. 
economic zone between Romania and Ukraine. The Court has constantly been of the view that small islands produce disproportionate effects on the delimitation of maritime zones. It appears that in the case at hand the ICJ aimed to remove any disproportion between the maritime zones of the States in order to achieve an equitable result. If Serpents' Island had been used for determining the base points and adjusting the provisional equidistance line, a disproportionate effect would have been given to the small island. Thus, in case of tiny Serpents' Island, the Court' most important purpose was to eliminate a disproportionate effect on the delimitation line which could have been generated by the island. It seems that the only possible solution was to disregard the island in the delimitation process.

The Romanian arguments were as follows:

- Serpents' Island is a rock within the meaning of Article 121(3) of UNCLOS $^{141}$;

- human survival on the island depends on supplies, especially water ${ }^{142}$;

- the presence of some individuals on official duty does not amount to sustained human habitation ${ }^{143}$;

- Serpents' Island does not form part of the coastal configuration of the States and therefore cannot be regarded as Ukraine's relevant coasts $^{144}$;

- Serpent's Island with its territorial sea might be considered as a relevant circumstance, but given the small size of the island, its effect on the delimitation should be very reduced or none. ${ }^{145}$

In light of the above, Romania contended that the island did not produce any effect beyond its 12 nautical miles territorial sea and, therefore, that the equidistance line should be shifted only to respect the maritime boundary along 12-nautical-mile arc around Serpents' Island ${ }^{146}$.

141 Reply of Romania, Chapter 5.

142 Memorial of Romania, at paras. 10.43-10.46; Reply of Romania, at para. 6.22.

143 Memorial of Romania, at paras. 10.6, 10.77.

144 Ibid., at paras. 3.36-3.38.

145 Reply of Romania, at paras. 6.25-6.36.

146 Judgment, at paras. 180-181. See for the general conclusions of Romania: Memorial of Romania, at paras. 10.132. 
Ukraine argued to the contrary. Its position relied on the argument that Serpents' Island constitutes an island within the meaning of Article 121(2) of UNCLOS and had a baseline which generated base points for the construction of the provisional equidistance line ${ }^{147}$. Moreover, the island may sustain human habitation and has an economic life of its own ${ }^{148}$. Finally, the island is provided with appropriate buildings and accommodation for an active population ${ }^{149}$.

International courts and tribunals have dealt with islands in a few cases concerning the maritime delimitation, some of which have resulted in the conclusion that the geographical characteristics of the island(s) in question called for the adjustment of the equidistance line. In Tunisia v. Libya the size and position of the Kerkennah Islands was considered as a relevant circumstance ${ }^{150}$. Similarly, the Seal Island (together with its smaller neighbour, Mud Island) was regarded as relevant "by reason both of its dimensions and, more particularly, of its geographical position"151. Thus, it might have appeared that the ICJ would uphold the Ukrainian claim. However, the Court always underlined, directly or indirectly, that the size and position of an island is the decisive factor in considering it as a relevant circumstances. The role to be played by an island depends on its geographical characteristic. In the present case, the ICJ once again reiterated that it had decided not to take into account of very small islands or had decided not to give them full potential entitlement to maritime zones "should such an approach have a disproportionate effect on the delimitation line under consideration"152. It also recalled its

147 Counter-Memorial of Ukraine, at paras. 7.27-7.46; Rejoinder of Ukraine, at paras. 5.4-5.13.

148 Counter-Memorial of Ukraine, at paras. 7.41-7.44.

149 Ibid., at para. 7.37; Judgment, at para. 184.

150 Continental Shelf (Tunisia/Libyan Arab Jamahiriya), supra note 4, at para. 128.

151 Delimitation of the Maritime Boundary in the Gulf of Maine Area, supra note 6, at para. 222. See also: Maritime Delimitation in the Area between Greenland and Jan Mayen, supra note 8, at para. 70; Anglo-French Continental Shelf Case, supra note 15, at paras. 243-245. Delimitation of the Maritime Boundary between Guinea and GuineaBissau, supra note 15, at para. 106.

152 Judgment, at para. 185. The ICJ quoted Continental Shelf (Libyan Arab Jamahiriya/ /Malta), supra note 5, at para. 64 (in which the Court found it equitable not to take account of islet of Filfla in the calculation of the provisional median line); Maritime Delimitation and Territorial Questions between Qatar and Bahrain, supra note 10, at 
previous conclusion that Serpents' Island could not serve as a base point for the purpose of the construction of the provisional equidistance line ${ }^{153}$. It thus indicated that the island would not be a relevant circumstance at the second stage of the delimitation process. Nonetheless the Court emphasized that, given this geographical configuration, any continental shelf and exclusive economic zone entitlements possibly generated by Serpents' Island could not project further than the entitlements generated by Ukraine's mainland coast. Any possible entitlements generated by the island in the eastward direction were fully subsumed by the entitlements generated by the western and eastern mainland coasts of Ukraine ${ }^{154}$. Ukraine itself did not extend the relevant area beyond the limit generated by its mainland coast, as a consequence of the presence of Serpents' Island in the area of delimitation ${ }^{155}$. Therefore, the Court decided that Serpents' Island did not call for an adjustment of the provisional equidistance line. With that in mind, the ICJ refrained from considering the much-discussed status of Serpents' Island under Article 121 of UNCLOS since it deemed the status of Serpents' Island as irrelevant to the case ${ }^{156}$. Nevertheless, the reasoning of the Court might seem to suggest that if it had had to apply Article 121 to Serpents' Island, it would have regarded it as a rock within the meaning of Article 121(3) of UNCLOS ${ }^{157}$.

para. 219; Territorial and Maritime Dispute between Nicaragua and Honduras in the Caribbean Sea, supra note 13, at paras. 302 et seq.) Also in the North Sea Continental Shelf cases, supra note 2, at para. 57, the ICJ stressed that the presence of islets, rocks and minor coastal projections had the disproportionally distorting effect and therefore they had to be ignored. In Award of the Arbitral Tribunal in the Second Stage of the Proceedings between Eritrea and Yemen, supra note 15, at paras. 147, the Tribunal stated that "their [the small single island of al-Tayr and the group of islands called al-Zubayr] barren and inhospitable nature and their position well out to sea ... mean that they should not be taken into consideration in computing the boundary line between Yemen and Eritrea". See also: J. M. Van Dyke, The Romania v. Ukraine Decision and its Effect on East Asian Maritime Delimitations', 'Ocean \& Coast Law Journal' 2010, Vol. 15, at pp. 261-262, 271-274.

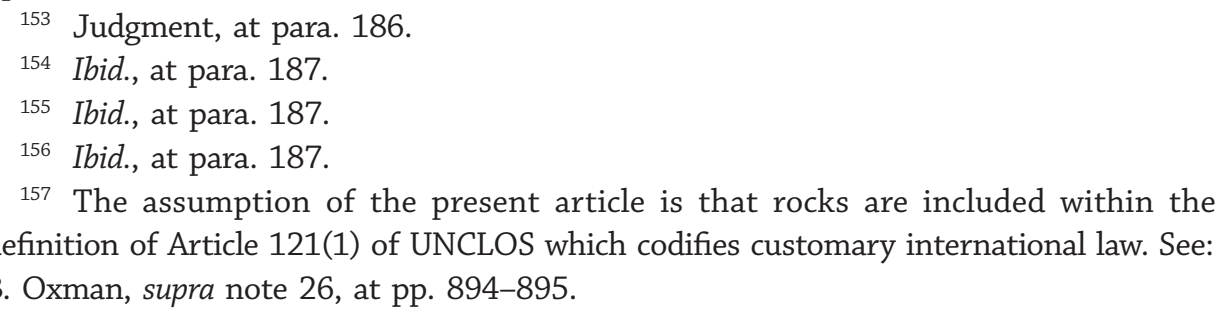




\subsubsection{The Conduct of the States \\ (Oil and Gas Concessions, Fishing Activities and Naval Patrols)}

Another relevant circumstance invoked by Ukraine concerned State activities in the relevant area. Ukraine licensed in 1993, 2001 and 2003 the exploration of oil and gas deposits within the areas claimed by Ukraine. Moreover, prior to 2001, Romania never protested against the activities in question in areas claimed by the applicant State ${ }^{158}$. Romania refused to consider the State activities in question as relevant circumstances ${ }^{159}$. Romania objected to the Ukrainian hydrocarbon activity and, what is more important, the dispute had crystallized up to 1997 when the States concluded the Additional Agreement. Thus two of the three licences were issued after the critical date $\mathrm{e}^{160}$.

As regards fishing activities, Ukraine argued that its claims corresponded to the limit of the States exclusive fishing zones. Ukraine was also active in policing its part of the disputed area. Conversely, Romania neither patrolled the area nor did it object to the Ukrainian activities $^{161}$. Romania disagreed with Ukraine, asserting that the practice of States had no bearing on delimitation, since neither State was economically dependent upon fisheries activity. Furthermore, the practice covered only a small part of the area and it had always been question by Romania. As regards naval patrols, they could not be considered as a relevant circumstance, since they occurred after the critical date ${ }^{162}$.

The Court rejected Ukraine's argument and thus upheld its cautious approach to resources as a relevant circumstance ${ }^{163}$. It referred to the case between Barbados and Trinidad and Tobago, in which the Arbitral Tribunal confirmed the cautious approach, stressing the fact that international courts and tribunals did not apply that factor as a relevant circumstance $^{164}$. As regards fishing activities, the ICJ underlined that only catastrophic repercussions for the livelihood and economic well-

158 Counter-Memorial of Ukraine, at paras. 8.39-8.57; Judgment, at paras. 189-190.

159 Reply of Romania, at para. 6.13; Judgment, at para. 193.

160 Reply of Romania, at paras. 7.3-7.39; Judgment, at paras. 193-194.

161 Counter-Memorial of Ukraine, at paras. 8.58-8.65; Judgment, at para. 191.

162 Reply of Romania, at paras. 7.40-7.60; Judgment, at para. 196.

163 Judgment, at para. 198.

164 Barbados v. The Republic of Trinidad and Tobago, supra note 15, at para. 241. 
being of the population would entail an adjustment of the provisional line ${ }^{165}$. The second option to justify an adjustment of the provisional line is a tacit agreement between States. In the case at hand, the Court stressed that Ukraine had not invoked the existence of such an agreement or modus vivendi between the States ${ }^{166}$. However, the jurisprudence of the ICJ suggests that it is possible to consider resources as a relevant circumstance. In the Continental Shelf case ${ }^{167}$ the Court took into account that circumstance and stated that:

"the Court could not fail to note the existence of a de facto line ... which was the result of the manner in which both Parties initially granted concessions for offshore exploration and exploitation of oil and gas. This line of adjoining concessions, which was tacitly respected for a number of years, and which approximately corresponds furthermore to the line perpendicular to the coast at the frontier point which had in the past been observed as a de facto maritime limit, does appear to the Court to constitute a circumstance of great relevance for the delimitation"168.

In the Gulf of Maine case, the Court referred to Continental Shelf case to reject the Canadian argument that there existed a "modus vivendi maritime limit" or a "de facto maritime limit" between Canada and USA ${ }^{169}$. It seems that the Court was of the view that only long, uniform and consistent practice of States may form a relevant circumstance, thereby edging it closer to a formation of customary rule. The ICJ reasoned as follows:

"even supposing that there was a de facto demarcation between the areas for which each of the Parties issued permits (Canada from 1964 and the United States from 1965 onwards), this cannot be recognized as a situation comparable to that on which the Court based its conclusions in the Tunisia/Libya case. It is true that the Court relied upon the fact of

165 Judgment, at para. 198. The ICJ quoted Delimitation of the Maritime Boundary in the Gulf of Maine Area, supra note 6, at para. 237.

166 Judgment, at para. 197.

167 Continental Shelf (Tunisia/Libyan Arab Jamahiriya), supra note 4, at pp. 83-85.

168 Continental Shelf (Tunisia/ Libyan Arab Jamahiriya), supra note 4, at para. 96.

169 Delimitation of the Maritime Boundary in the Gulf of Maine Area, supra note 6, at paras. 149-151. 
the division between the petroleum concessions issued by the two States concerned. But it took special account of the conduct of the Powers formerly responsible for the external affairs of Tunisia - France - and of Tripolitania - Italy, which it found amounted to a modus vivendi, and which the two States continued to respect when, after becorning independent, they began to grant petroleum concessions".

Moreover, in the Chamber's opinion the period from 1965 to 1972, "at least", which, according to Canada, is the one in which the modus vivendi was instituted, is too brief to have produced a legal effect of this kind, even supposing that the facts are as claimed ${ }^{170}$.

Therefore, it seems that only uncontested State practice lasting for a number of years with respect to maritime resources would be capable of being regarded as a relevant circumstance in the delimitation process. Since the Ukrainian activities did not fulfil those criteria, the Court rightly rejected the Ukrainian claim.

\subsubsection{Any Cutting-Off Effect}

The Court was also obliged to consider the principle of nonencroachment and any possible cut-off of the maritime entitlements of either State in the context of relevant circumstances. That principle is defined in the jurisprudence of the ICJ in the following way:

"principle of non-encroachment by one party on the natural prolongation of the other ... is no more than the negative expression of the positive rule that the coastal State enjoys sovereign rights over the continenta1 shelf off its coasts to the full extent authorized by international law in the relevant circumstances"171.

Both States argued before the Court that their own proposed maritime boundary did not cut-off the entitlements to the continental shelf and to the exclusive economic zone of either Romania or Ukraine.

170 Ibid., at paras. 150-151.

171 Continental Shelf (Libyan Arab Jamahiriya/Malta), supra note 5, at para. 46. See also: North Sea Continental Shelf, supra note 2, at paras. 44, 101(C)(1); Maritime Delimitation in the Area between Greenland and Jan Mayen, supra note 8, at para. 59; Barbados v. The Republic of Trinidad and Tobago, supra note 15, at paras. 320, 339-381. 
Conversely, both Romania and Ukraine claimed that the other State encroached on the natural prolongation of its territory and its claims led to a cut-off of maritime entitlements ${ }^{172}$. The Court observed that the line proposed by each State significantly curtailed the entitlement of the other State to the continental shelf and to the exclusive economic zone. However, the provisional equidistance line projected by the Court contained no such drawbacks as it allowed the States' coasts "to produce their effects, in terms of maritime entitlements, in a reasonable and mutually balanced way"173. Therefore, the ICJ rejected all the claims in this regard.

\subsubsection{Security Considerations}

A similar observation was put forward by the Court with respect to security considerations. Both States argued that the provisional equidistance line of the other State ran unreasonably close to its coasts and thus encroached on its security interests ${ }^{174}$. The Court confirmed that legitimate security considerations may play a role in determining the final delimitation line ${ }^{175}$. However, it once again observed that its provisional equidistance line differed from the lines proposed by the States and fully respected the legitimate security interests of either State ${ }^{176}$.

\subsection{The Third Stage - The Disproportionality Test}

Having found no relevant circumstances in the present case, the Court proceeded to the final stage of the delimitation process, involving verification of the line to check whether it would lead to an inequitable result by reason of any marked disproportion. Before considering the

172 Judgement, at paras. 199-200. See: Memorial of Romania, at paras. 12.1-12.13; Reply of Romania, at paras. 9.32-9.36; Counter-Memorial of Ukraine, paras. 6.32-6.34, 10.23-10.25; Rejoinder of Ukraine, at paras. 8.22-8.25.

173 Judgment, at para. 201.

174 Ibid., at paras. 202-203; See: Memorial of Romania, at paras. 12.14-12.19; Reply of Romania, at paras. 9.37-9.41; Counter-Memorial of Ukraine, at paras. 8.22-8.27; Rejoinder of Ukraine, at paras. 10.26-10.27.

175 It referred to Continental Shelf (Libyan Arab Jamahiriya/Malta), supra note 5, at para. 51.

176 Judgment, at para. 204. 
case at hand, and any possible adjustment of the line in order to achieve equitable solution, the Court made some general comments and referred to the jurisprudence of international courts and tribunals.

The first point made by the ICJ concerned disproportionality between the respective coastal length and the apportionment of areas that ensue. The purpose of the disproportionality test is to avoid inequity ${ }^{177}$. The Court stated that only significant disproportionality may call for any adjustment of the provisional line ${ }^{178}$. To be more accurate and eloquent, it quoted the Arbitral Tribunal in Anglo-French Continental Shelf stating that:

"it is disproportion rather than any general principle of proportionality which is the relevant criterion or factor ... there can never be a question of completely refashioning nature ... it is rather a question of remedying the disproportionality and inequitable effects produced by particular geographical configurations or features"179.

The above quotation suggests that the Court does not see fit to refashion any disproportionality since its task is limited to ensuring that an equitable solution is reached between the parties concerned. The test of proportionality is not an independent factor and it stems from these equitable principles ${ }^{180}$.

Secondly, and consequently, maritime zones are not to be assigned in proportion to the length of the respective coastlines ${ }^{181}$. Moreover, the checking of proportionality is approximate ${ }^{182}$. Since no exact techniques have been developed to establish the existence of significant disproportionality, the Court employs a case-by-case approach and stated that it "remains in each case a matter of its appreciation, which it will exercise by reference to the overall geography of the area"183. Thus the

177 See: Delimitation of the maritime boundary between Guinea and Guinea-Bissau, RIAA, Vol. XIX, at paras. 94-95; Black Sea, at paras. 110, 211-213.

178 Ibid., at para. 210.

179 Anglo-French Continental Shelf Case, supra note 15, at para. 101.

180 See: North Sea Continental Shelf, supra note 2, at para. 91.

181 Judgment, at para. 211. The ICJ also underlined that it would check, ex post facto, on the equitable nature of its line by referring to Delimitation of the Maritime Boundary between Guinea and Guinea-Bissau, supra note 15, at paras. 94-95.

182 Judgment, at para. 212.

183 Ibid., at para. 213. 
criterion of geography is crucial for the determination of the existence of significant disproportionality.

Going back to the third stage of the Romania-Ukraine equidistance line, the Court briefly noted that the ratio of the respective coastal lengths for Romania and Ukraine was approximately 1:2.8 and the ratio of the relevant area between Romania and Ukraine was approximately 1:2.1 ${ }^{184}$. Therefore, the ICJ rejected the argument that "the line as constructed, and checked carefully for any relevant circumstances that might have warranted adjustment, requires any alteration"185. Consequently, it confirmed its provisional equidistance line as the maritime boundary delimiting the continental shelf and the exclusive economic zone of Romania and Ukraine ${ }^{186}$.

\section{Concluding observations}

The main function of delimitation in the law of the sea is to separate maritime zones of adjacent or opposite States. To this end, the delimitation process focuses on drawing a single maritime boundary. The aim of delimitation is to achieve an equitable solution and it is realised by considering relevant circumstances and checking whether there is disproportionality between the respective coastal length and the apportionment of maritime areas.

The judgment in the Black Sea case has evidenced that there are no discernible criteria of equity which should inevitably be employed during maritime delimitation. The Court prefers a case-by-case approach to maritime delimitation and the geographical configuration of coastline in a given case seems to be the most important element demanding the application of certain equitable principles to maritime delimitation. In other words, the question as to whether and which equitable principles should be applied in a given case will always depend on the geographical configuration of the delimitation area. The ultimate goal, however, remains the same and seeks to achieve an equitable solution to delimitation

184 Ibid., at para. 215.

185 Ibid., at para. 216.

186 Ibid., at paras. 217-219. 
disputes. In this regard, the Black Sea case may serve as a substantial guideline in conducting delimitation exercises and in assessing the relevant circumstances to be taken into account during future delimitation disputes.

The delimitation process presents a host of difficulties. The categories of relevant circumstances continue to expand as an ever-increasing range of factors is advanced by States as having potential relevance to delimitation disputes ${ }^{187}$. However, a factor which is identified by a State as a possible relevant circumstance need not to be treated as such. For example, in the present case the Court took no account of the length of coasts, since the difference was insubstantial. In this context, it must be noted that geographical factors constitute the most important equitable principles in the considerations of the ICJ. In the case at hand, the Court dismissed all arguments concerning the adjustment or shifting of the provisional equidistance line as being of little, if any, relevance to the maritime delimitation. The Court's stance on the issue was, however, dictated by the fact that its provisional line departed from the lines proposed by both States. Therefore, the ICJ itself drew a single maritime boundary which has, at least to some extent, reconciled the positions of the States.

Few lawyers envisaged that the modest beginnings of maritime delimitation in the jurisprudence of the Court would be so enriched by its subsequent decisions. The Court has heavily relied on its earlier jurisprudence in order to establish a consistent methodology on maritime delimitation. In the present case the Court, for the first time, referred to a "delimitation methodology" and thus confirmed rules which were already developed and substantiated in its previous decisions. In this context, it should be underlined that international jurisprudence on maritime delimitation has in practice a law-making character ${ }^{188}$. The judgment illustrates the overall process of the maritime delimitation with a high degree of transparency, especially with respect to the three stages of maritime delimitation. However, the Court's ruling does not

187 M. D. Evans, supra note 73, at p. 32.

188 See: Dispute concerning Delimitation of the Maritime Boundary between Bangladesh and Myanmar in the Bay of Bengal, supra note 16, Declaration of Judge Wolfrum, at p. 3. 
contain any new significant developments with respect to the principles of maritime delimitation itself, especially as regards the underlying equitable principles. It simply reaffirmed previous rules on maritime delimitation and expressed them in a more transparent way. Nonetheless, the judgment of the Court should be seen in the larger context of assuring a single, certain methodology for maritime delimitation. It reflects the general attitude of the Court towards equitable principles, according to which maritime delimitation as such should "display consistency and a degree of predictability; even though it looks with particularity to the peculiar circumstances of an instant case, it also looks beyond it to principles of more general application"189.

189 Continental Shelf (Libyan Arab Jamahiriya/Malta), supra note 5, at para. 45. The Court further quoted its previous decision in Continental Shelf (Tunisia/Libyan Arab Jamahiriya), supra note 4 , at para. 71 , to state that: "[t]his is precisely why the courts have, from the beginning, elaborated equitable principles as being, at the same time, means to an equitable result in a particular case, yet also having a more general validity and hence expressible in general terms". 